\title{
Gregory Of Nazianzus' Trinitarian Argument in Oration 23
}

DENNIS P. BRAY

St Andrews University

db237@st-andrews.ac.uk

\begin{abstract}
In his Third Oration on Peace Gregory of Nazianzus seeks to refute Eunomian claims that the Son and Spirit do not proceed from God's essence and, therefore, are not fully divine. To do so, Gregory modifies a piece of triadic speculation-used by Origen and others-to fit his particular polemical and doctrinal needs. My aim in this study is to give an exposition of Gregory's argument. After outlining the main points of Eunomius' view of the Son's deity, I investigate the four dilemmas that compose Gregory's anti-Eunomian argument. The argument is negative insofar as it attacks Eunomius' brand of trinitarianism directly. Even so, in the wider rhetorical context of Oration 23 this argument leads naturally into a positive account of the Father's essential production of the Son and Holy Spirit. I conclude by detailing some of the main moves of this positive trinitarian theology.
\end{abstract}

Keywords: Trinity, Gregory of Nazianzus, Pro-Nicene, Orthodoxy, Homoousion/consubstantiality

\section{Introduction}

Oration 23, the Third Oration on Peace, is one of Gregory of Nazianzus' most important trinitarian texts. ${ }^{1}$ In it, he seeks to refute the Eunomian claims that the Son and Spirit do not proceed from God's essence and are therefore not fully divine. His refutation includes the following argument,

You posit not a single nor an uncompounded nature of divinity but either three that are alienated and disjoined from one another and, not surprisingly, in conflict by virtue of their being proportionately superior or inferior; or you posit a single nature, but one that is constricted and mean, and which is not in a position to be the source of anything significant precisely because it cannot or will not, and this for two reasons, either envy or fear: envy, because it wishes to

\footnotetext{
${ }^{1}$ Christopher Beeley (2008) considers the four "major [trinitarian] doctrinal statements" to be Orations 20, 23, 25, and the Theological Orations taken as a set (190ff).
} 
avoid the introduction of something that is of equal importance; fear, lest it take on a hostile and belligerent element. $(2003,23.6)$

This brief passage-henceforth 'The Argument' - presents a series of dilemmas meant to undercut the heterousian position and bolster Gregory's own form of pro-Nicene trinitarianism. The line of thought Gregory pursues here is not unique to him, but has roots going back at least to Plato, and variants were employed by Gregory's immediate intellectual predecessors, and several of his contemporaries. ${ }^{2}$ Gregory's formulation stands out from these for its subtlety and novel variations on the theme. How specifically did Gregory employ The Argument, and was it effective in countering Eunomian advances? Additionally, how does The Argument relate to Gregory's wider trinitarian theology, particularly as developed in Oration 23?

In this study I will address these questions. Taken as a whole Oration 23 is a masterful sermon worthy of dedicated attention-attention not yet received. ${ }^{3}$ The present study is intended to be a first step toward this end; my hope is that better understanding of one of its parts will contribute to a deeper understanding of the whole. The part on which I focus sets the polemical portion of the oration into motion, ${ }^{4}$ and reflects many of the rhetorical and theological moves Gregory develops throughout the Third Oration on Peace.

\section{Opening salvo: You posit not a single nor an uncompounded nature of divinity...}

By the time Gregory stepped up to the pulpit to deliver Oration 23, theological controversy had been building in the East for some time, particularly in its capital, Constantinople. Since the 350s Eunomius and his teacher Aetius had been active in pushing their theological agenda in the Imperial court and among other influential elite. While there was some early success on this front, heterousian efforts in the political sphere slowed to a standstill in the 380s (see Vaggione 2008, chp.7). At the same time, Eunomius worked from the bottom up. Along with several prominent heterousians, he formed a counterpart organization complete with bishops, priests, and churches through which they continued instruction and liturgy. Heterousian missionaries busily worked to convert non-heterousian

\footnotetext{
2 I discuss some of these in Dilemma 3 of this paper. This type of argument would continue to be employed by trinitarian thinkers from Augustine to Richard of St. Victor and Bonaventure. Along with the arguments of these medieval thinkers it is an antecedent to those employed by contemporary philosophers of religion such as Richard Swinburne (1994, chp.8), Stephen T. Davis (2016, 65-68), and William Hasker (2013, 220-223).

${ }^{3}$ McGuckin (1994) gives it sporadic attention.

${ }^{4}$ Gregory addresses his theological opponents directly in parts 6-10; he develops his doctrine throughout 6-12.
} 
Christians throughout the East, including Constantinople. ${ }^{5}$ Alongside the political, ecclesial, and missionary activity, a war of ideas had been waged in print for several decades. Around 360 Eunomius published his Apology; Basil responded a few years later with Against Eunomius, followed by Eunomius' Apology for the Apology in the late 370s. By late 380 the situation came to a boil. Theodosius issued his famous Cunctos Populous which defined catholic faith in part as belief "in the one Divinity of the Father and of the Son and of the Holy Spirit," and decreed this as the official religion of the empire. The decree was met with immediate resistance: there were protests, church interruptions, Gregory's church-building was vandalized, rocks were thrown at him and his congregants, and an attempt was made on his life (Gregory awoke with the would-be assassin at his bed-side in tears, confessing to the plot) (Beeley 2008, 36ff).

It was within these tendentious circumstances that Gregory pleaded to his congregants to react in peace, but also combatted Eunomius' brand of trinitarianism. The Argument's primary target is the idea that the Son (and by extension, the Holy Spirit) is not produced from God's essence, but has a different-and ontologically inferior-nature than the one true divinity. Gregory's main goal in Oration 23 is to persuade his listeners that the doctrine is bankrupt and he uses every tool available to him rhetorically, theologically, philosophically, and conceptually. ${ }^{6} \mathrm{He}$ begins the refutation by telling his theological opponents that on their view, the divine nature ( $\theta \varepsilon$ ó $\tau \eta \tau o \varsigma ~ \varphi v ́ \sigma \iota v)$ is

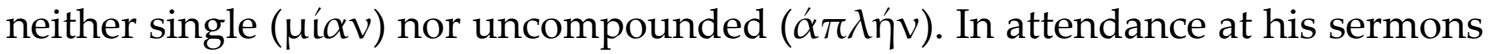
would have been homoousians, homoians, pneumatomachians, and heterousians. To the latter, in particular, Gregory could hardly have made a more

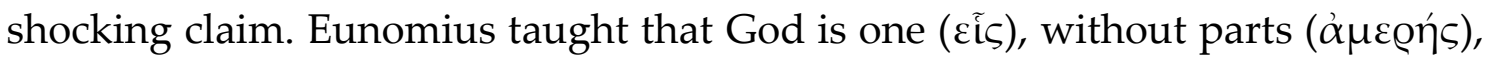

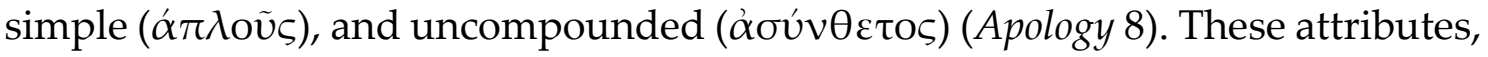
along with the claim that the Son is essentially distinct and inferior to the Father, all result from Eunomius' fundamental doctrine that God's essence is to be

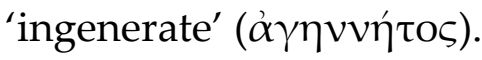

\footnotetext{
${ }^{5}$ On the philosophical nature of the Eunomian apologetic approach see Stępien and Kochańczyk-Bonińska (2018, chp.3).

6 "[O]ne of the most distinctive aspects of Gregory's doctrine", Beeley (2008) notes, "is the way in which he moves so easily between simple doxology and fine conceptual work." He continues, "Gregory is aware that more technical theological analysis is highly specialized in comparison with everyday Christian language, and therefore out of the reach of most believers; and he even complains about the risk that is poses of dissolving the faith into 'sophistics' (25.17). Yet at the same time he is insistent that higher levels of theological understanding build upon the foundation of basic faith and that advanced language always serves to articulate that same faith" (188). Gregory's willingness to work on both simple and advanced levels shows in Oration 23 and will ultimately play an important part in the large-scale adoption of the pro-Nicene position. I will say more about this in the final section.
} 
For Eunomius and Aetius, ingenerateness expresses the idea that God is completely uncaused: he has no prior cause, nor is he self-caused. In their study on divine incomprehensibility during the $4^{\text {th }}$ century, Tomasz Stępien and Karolina Kochańczyk-Bonińska summarize Aetius' position,

In Syntagmation, we find frequent claims on the transcendence of God the Father.

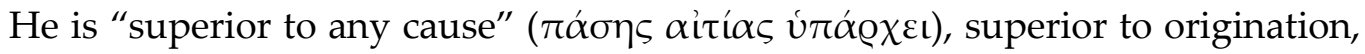
surpasses every nature, and, therefore, God cannot be even called self-caused. Simultaneously, we have a precise indication of the essence of God. The term "ingenerate" ( $\alpha \gamma \varepsilon v v \eta \dot{\tau o \zeta)}$ plays the central role because it allows [us] to know who God is and it alone properly names His essence. Aetius treats "ingeneracy" as the very name which is intrinsic to the substance and is revelatory of the essence... (Stępień and Kochańczyk-Bonińska 2018, 90-91)

Ingeneracy, then, is the fundamental characteristic of God and is therefore his most fitting name. From this stance on God's ingeneracy follows a corresponding strong stance on God's transcendence, placing strict limitations on divine causality. God cannot cause in the sense of natural-that is, essentialproduction. This for several reasons. One is that Eunomius understood divine production in physical terms, where an essence is shared only if it is divided. ${ }^{7}$ But he denied that the divine essence could be divided; this is impossible given their view of simplicity as it would allow for the divine essence to be split apart, changed, and degenerated (Apology 9). Second, if God produces essentially, two entities would share the very same essence, making the divine essence compound. Again, a conclusion that strict divine simplicity does not allow (Apology 10). Third, and most important to Eunomius, the product of essential causation shares the essence of its cause, resulting in a conceptual contradiction: to be the divine essence is to be ingenerate; but if, per impossibile, the Son is generated essentially, then he is both generated (because Son), and ingenerate (because he has the divine nature) (Apology 13). Michele René Barnes has written extensively on the nature of causality in $4^{\text {th }}$ century trinitarian theology and summarizes Eunomius' position (1998),

For Eunomius the transcendence of God requires that He cannot be understood to generate a product which has the same kind of existence He has, since that kind of existence is to be uncaused or unproduced, and any product will necessarily (i.e. by definition) be caused. The uniqueness of God's kind of existence means that any productivity must exist outside His nature. (62)

\footnotetext{
${ }^{7}$ Neither Aetius nor Eunomius could look past the physical connotations, long part of Greek ontology, which accompanied any talk of generation from ousia. See Barnes (2016, 175-179; fn. 18).
} 
For these reasons the Son cannot be caused essentially, and Eunomius finds an

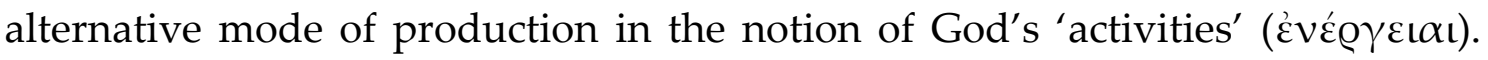
Barnes (1998) again helpfully summarizes Eunomius' position,

The uniqueness of God's kind of existence means that any productivity must exist outside His nature...According to Eunomius, God's productive capacity can only be that of an activity, energeia, which is external to the essence. This external productive activity is that of creating, the only sort of divine production that Eunomius recognizes. God's own activity of creating is limited to the production of the second Person; the second Person creates everything else. (60)

Eunomius, then, holds a high view of God's transcendence, expressed through his position on God's unique ingenerate nature and God's single act of indirect causation via the will as his energeia. While holding this high view of divine transcendence, Eunomius simultaneously maintains that Christ is divine. There is a tension between these two ideas which we can see in a brief passage from the Apology,

We assert that 'the God of all things' is the one and 'only true God'...being, in accordance with his pre-eminence, incomparable in essence, power, and authority, he begot and created before all things as Only-begotten God our Lord Jesus Christ... This only begotten God is not to be compared either with the one who begot him or with the Holy Spirit who was made through him, for he is less than the one in being a 'thing made', and greater than the other in being a maker.

Here Eunomius clearly states that the Ingenerate God is the "one and only true God", and yet he also seeks to recognize the Son as divine in some sense. It is this tension between the existence of two (or perhaps three) Gods, and only one of them being the "true" God, which Gregory attempts to press to the breaking point. He does this in The Argument by presenting the heterousian with a series of dilemmas. Outlined briefly, Gregory argues that on the Eunomian view,

1. There is either a plurality of divine natures, or one divine nature.

2. If a plurality of divine natures, then either the divine beings are hierarchically arranged, or they are not.

3. If one divine nature, God does not share the divine essence because either he cannot, or he will not.

4. If God wills not to share the divine essence, he does so because he is either envious, or fearful. 
Each dilemma offers a straightforwardly unacceptable conclusion about God, or another dilemma with similarly unattractive options. Let us look at each dilemma in turn.

\section{Dilemma 1-the status of the Son's divinity}

That Eunomius posits at least one divinity is beyond dispute, but what about the Son? Is he, too, divine? We will look at three ways Eunomius answers in the affirmative. As we do, it will be helpful to bear in mind the imaginative middle ground between full divinity and creation which many in the fourth century held. On this point, Lewis Ayers (2004) reminds us that,

At issue until the last decades of the controversy was the very flexibility with which the term 'God' could be deployed. Many fourth-century theologians easily distinguished between 'God' and 'true God'. In discussions of the relations between the Son the Father, or between creation and generation, arguments about the 'grammar' for talking about God were also under way. (14)

A conceptual space which allows for degree of deity runs counter to modern sensibilities. But this fact only underscores the long-term effects of pro-Nicene achievements, as Ayers (2014) elsewhere concludes, "the ease with which this distinction [between divine and created] can be made by modern theological readers is itself an achievement of the fourth century" (4). Therefore, as we seek to understand Eunomius' thoughts on the Son's divinity, we must remain sensitive, on the one hand, to "fourth century theologians... [who] made distinctions between being 'God' and being 'true God,'" and, alternatively, our own adoption of pro-Nicene thought by which we "articulate a clear principle that whatever is God...admits of no degrees."

One last point of historical context: the Apology is directed mainly against homoiousion interlocutors, intent upon elevating the Son (and Spirit) to a share of God's nature. ${ }^{8}$ To counter this, Eunomius spends much more time explaining the ways in which the Son does not share the divine nature than the ways which the Son can be said to be divine. Even so, we find Eunomius in several places declaring the Son's deity. ${ }^{9}$ How should we understand Eunomius' view of the Son? From his extant writings, there are at least three reasons why-or perhaps better, three ways in which - the Son is divine. First, the Son is God's special and

\footnotetext{
${ }^{8}$ According to Vaggione (2008, 161-179), at the time of writing the Apology, the incipient proNicene movement was not enough of a threat to be on Aeutius or Eunomius' theological radar.

${ }_{9}$ For example, calling the Son "Only-begotten God" in Apology 15.
} 
only creation. ${ }^{10}$ As such, the Son is subordinate to nothing else in the universe except the Father:

We do not, however, include the essence of the Only-begotten among things brought into existence out of nothing, for 'no-thing' is not an essence. Rather, on the basis of the will of the one who made him we establish a distinction between the Only-begotten and all other things, affording him that same pre-eminence which the maker must necessarily have of his own products. (Apology, 15)

According to this passage the son's penultimate place on the hierarchy of being results from his being begotten by the Father, and being the Father's only begotten. In addition to being God's only creation, the passage further specifies that the Son is specially created by God's will. This is the second reason for believing the Son is divine. Continuing in the passage just quoted, Eunomius expands on the relationship between the Son's unique causation and his eminence,

Since he alone was begotten and created by the power of the Unbegotten, he became the perfect minister of the whole creative activity and purpose of the Father.

As the product of the divine will, the Son has an exalted position on the hierarchy of being and, what is more, he is in perfect accord with his Father, making him uniquely placed for acts of creation and salvation. As the creator of the cosmosi.e., the rest of creation - "he is therefore the Only-begotten God of those things which came into existence after him and through him." For Eunomius, divinity is a function of causation: God is 'God over all' and the 'One true God' because he is the ultimate cause of all other existents. As the penultimate cause, the Onlybegotten is not God-to-the-Father, but he is God-to-creation. ${ }^{11}$

Third, the Son is worthy of great honour. This because of both his value, as the penultimate being, and his creative and salvific actions. ${ }^{12}$ Like the Father, the Son "too conforms to the dignity of its nature." That is, the Son's placement on the theological hierarchy results in a degree of honour second only to God's. In one

10 Barnes (2006) notes Eunomius' hesitancy in calling the Son 'created' and his careful explanation that the Son is not a product like the cosmos (196).

11 Gregory attacks this functionalism in 23.10 with an argument ad absurdum: "Trinity does not mean an itemized collection of disparate elements; if it did, what would prevent us from calling it a decad, or a centad, or a myriad, if the number of components so justified?" In other words, if divinity is a function of causality, then each cause is 'God-to-its-effect' such that "the arithmetical possibilities are many". Many indeed, since on this account there are as many Gods as there are causes.

12 Eunomius argues that although "the saviour himself" acknowledges "the Only true God", this does not "take away the godhead of the Only-begotten" (Apology 21). 
place Eunomius indicates that honour appropriate to the Son includes worship. The Son creates not according to his will, but solely "at the Father's command and acknowledges that he can do nothing of his own accord, just as the one who is worshipped is different from the one who worships." 13

The Son, then, can be viewed as divine in at least three ways. First, he is God's unique creation. Second, he is specially synced to God's will and thus specially placed to create and save the cosmos. Third, he deserves honour, and possibly worship, second only to the Father. This third reason is relatively minor in Eunomius' system. ${ }^{14}$ The first two receive the most attention, and Barnes (2016) summarizes them this way,

When Eunomius discusses the Son's production, his purpose is to establish that since the Son is created directly by God's will, His essence is prior to all other created essences and is, by virtue of its one prior cause, unique among all created essences. Eunomius describes the Son as the exclusive product of the Father, and maintains that it is the Son who produces "creation," or the cosmos. Though the Son is himself a product... [he is] a creature who, if not God, is nonetheless unlike other creatures. (196)

Here Barnes also notes Eunomius' ambiguity on the status of the Son's divinity. The Son is "a creature who, if not God, is nonetheless unlike other creatures."

For the sake of argument let us assume that Eunomius views the Son as divine. Even so, Gregory states that Eunomius posits three divine natures. Such a claim is not unreasonable given the latter's teaching that "the Counsellor...is third in both dignity ( $\dot{\alpha} \xi \iota \omega \mu \alpha \tau \iota)$ and order ( $\tau \dot{\alpha} \xi \varepsilon \iota)$, we believe that he is third in nature as well," and "He is honoured in third place as the first and greatest work of all, the only such 'thing made' of the Only-begotten..." (Apology 25) Statements like this leads Gregory to conclude that Eunomius posits three divine natures. But this conclusion is overly generous given Eunomius' express thoughts on the matter. For instance, the previous quotation Eunomius continues: “...lacking

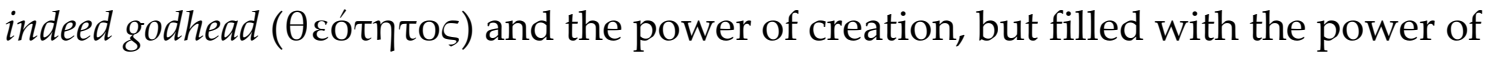
sanctification and instruction."

Thus Eunomius certainly posits three eminent natures, natures thoroughly unique among and stationed above all others. I think Eunomius cannot correctly

${ }^{13}$ Apology 20. In a note from the critical apparatus, Vaggione (1987) identifies the last sentence of this passage as a reference to John 16:14 (60). If so, it is the only instance in the Apology that Eunomius mentions worship of the Son as a fitting aspect of his dignity and place on the ontological hierarchy.

${ }^{14}$ Certainly, one way to appropriately honour the Son is to accurately identify his place in the ontological hierarchy, and to correctly describe it in one's theological system. Beyond this, Eunomius does not elaborate on what honouring the Son might look like. Gregory, however, develops the theme in great detail in Oration 23. 
be said to have posited three divine natures-Gregory's accusation on this point is likely attributed to his desire to kill two theological birds (viz., heterousians and pneumatomachians) with one rhetorical stone. Little hangs on this though. Still, Gregory's main point still stands: essentially distinct divinities are "alienated and disjoined" from one another. A point Gregory pursues in the second dilemma.

\section{Dilemma 2-multiple divine natures: alienation and conflict}

If the Eunomian admits the existence of multiple divine natures, she faces a theological situation in which the divine beings "are alienated and disjoined from one another and, not surprisingly, in conflict by virtue of their being proportionately superior or inferior." At this stage The Argument makes three claims about the Eunomian view needing examination.

(Claim 1) If there are multiple divine natures, then the natures are hierarchically arranged.

(Claim 2) If the divine natures are hierarchically arranged, then they are disjoined from one another.

(Claim 3) If the divine natures are hierarchically arranged, then they conflict with one another.

All parties agree upon the veracity of Claim 1. Eunomius is quite explicit on the matter: "the order of each conforms harmoniously to its nature, so that the first in order is not second in nature and the first in nature is certainly not allotted second or third place in the order" (Apology 25). How does a being's nature $(\varphi v ́ \sigma \iota v)$ determine its order $(\tau \alpha \dot{\xi} \xi \varepsilon)$ to other beings? Our discussion from the previous section is helpful here because Eunomius views the hierarchy of natures primarily as a matter of causation. The more productive-or potentially productive- a being, the greater its nature and, therefore, the higher its order among others. In these ways Eunomius readily admits the strict subordination of Son to Father, and Holy Spirit to Son.

Claims 2 and 3 are not obviously true and, depending on the sense in which we understand them, are probably not propositions Eunomius would grant. To test the claims, we must clarify what Gregory means by 'disjoined' and 'conflict' before moving to his reasons for finding these in Eunomius' doctrine. The idea that Arian theology made the divine hypostases disjoined, or 'estranged' ( $\dot{\alpha} \pi \varepsilon \xi \varepsilon v \omega \mu \varepsilon \dot{\varepsilon} v \alpha \varsigma$ ), from each other had been circulating in the East for some time. Dionysius of Alexandra, Dionysius of Rome (both c.250), and Athanasius each 
employed similar language. ${ }^{15}$ Gregory raises the idea in several other places, such as Oration 31 where he says of the three persons,

one is not more and another less God; nor is One before and another after; nor are They divided in will or parted in power; nor can you find here any of the qualities of divisible things; but the Godhead is, to speak concisely, undivided in separate Persons. (Oration 31.14)

Gregory here explicates some acceptable and unacceptable forms of division. The last sentence in the passage is more helpfully translated "the Godhead is in separates unseparated" or "undivided in its divisions"16 - where the 'divisions'

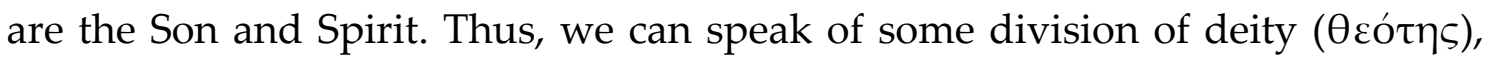
namely, division between persons. However, Gregory refuses to countenance any division that entails axiological hierarchy ${ }^{17}$, temporal separation, ${ }^{18}$ or division of power and will. For Gregory, Eunomius' hierarchical doctrine fails at all these points.

Gregory elaborates on the theme of division in Oration 20. There he writes of the importance to not "adopt the insanity of Arius and divide them [the Father,

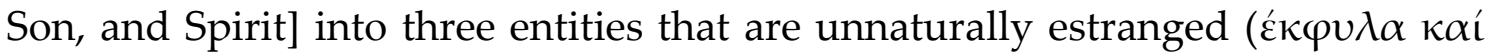
$\alpha \lambda \lambda$ ót@ı $\alpha$,) from one another." Later he again picks up the thought: "Nor, on the

${ }^{15}$ Dionysius of Alexandra: "If by the hypostases being three they [i.e., Arians] say that they [the hypostases] are divided, there are three, though they like it not. Else let them destroy the divine Trinity altogether." Quoted by Basil of Caeseria (De Spiritu Sancto, 72). Dionysius, Bishop of Rome elaborated upon a similar idea: "Next, I may reasonably turn to those who divide and cut to pieces and destroy that most sacred doctrine of the Church of God, the Divine Monarchy, making it as it were three powers and partitive subsistences and god-heads three. ...but they in some sort preach three Gods, as dividing the sacred Monad into three subsistences foreign to each other and utterly separate." Quoted by Athanasius (De Decretis VI.26). Athanasius: "Neither can we imagine three subsistences separated from each other"; and elsewhere, "we made enquiry of

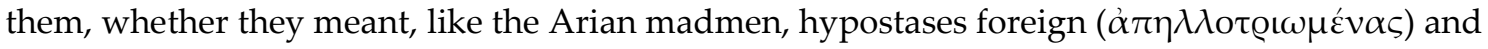

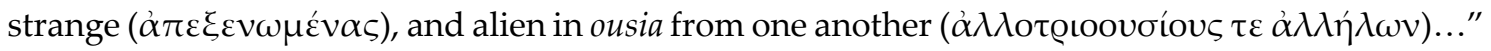
(Tome of Antioch 5).

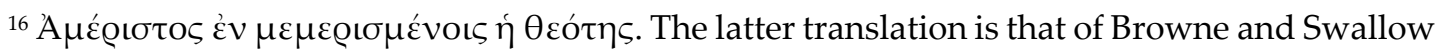
(1886, VII).

${ }_{17}$ At times, such as explaining the meaning of John 14:28, Gregory describes the Father as greater (Oration 30.7). However, Gregory is always careful to point out the Father possesses the fullness of divinity of himself (he is uncaused), and that the Father shares that fullness with the Son and Spirit. Thus, the Father possesses no good which is not also had by the Son and Spirit. We may say, then, that Father has a certain conceptual priority, but no actual, axiological, superiority. Thanks to Oliver Langworthy for bringing this distinction to my attention.

${ }^{18}$ For Eunomius, the Son is outside of or before time (chronos), but within the ages (aeons). Gregory makes no such distinction; generation of Son and Spirit are not temporal in any way. However, the eternal relations between the persons are far from static: their eternal "movement" is highly dynamic (cf. Oration 38.8). (See Langworthy, 2019, pp.19ff.) 
other hand, ought we divide them into three substances that are either foreign

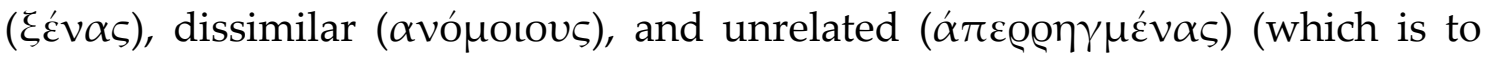

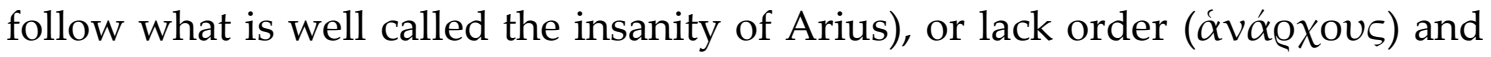

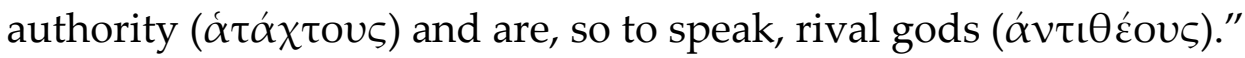

Taking Orations 31 and 20 into consideration along with $23,{ }^{19}$ we see that essentially distinct divinities are comparable to being estranged, strangers, and foreigners. These metaphors may have been convincing to the 'simpler sort,' those laymen inclined toward Eunomianism, ${ }^{20}$ but does Claim 2 go beyond metaphor? If Claim 2 is to have greater force against the Eunomian, Gregory must show that ontological separation presents a more substantive problem for her position. We may develop an argument toward this end. ${ }^{21}$

To begin with, Eunomius makes claims about the close relationship between the Father and Son. The Son is brought into existence purely by the Father's good will, the "Only-begotten exists by virtue of the will of the Father," (Apology 24) he "serves the law of the Father," and creates "at the Father's command and acknowledges that he can do nothing of his own accord" (Apology 20). The close relationship Eunomius describes is intuitively attractive and captures important scriptural data. Beyond this, though, Eunomius' doctrine of creation and salvation depend upon a tight relationship between Father and Son. Eunomius makes clear that God's "will is sufficient to bring into existence and to redeem all things," and God accomplishes his will in these areas through the Son. The following credal statement captures the Son's activities as executer of the Father's will,

For we confess that only the Son was begotten of the Father and that he is subject to him both in essence and in will (indeed, he himself has admitted that he 'lives because of the Father' and that he can 'do nothing of his own accord')...that what the Son is everlastingly is what he is also rightly called: Offspring, obedient Son, most perfect Minister of the whole creation and will of the Father, ministering for the maintenance and preservation of all existing things, for the giving of the Law to mankind, for the ordering of the world and for all providential care...In these last days he was born of the holy Virgin, lived in holiness in accordance with human laws, was crucified, died, rose again the third day, and ascended into heaven. He will come again to judge both the living and the dead by a righteous

19 Gregory gives a similar argument in Oration 25.16, "Neither should we posit three first principles if we want to avoid the polytheism of the Greeks, nor a single one, Judaic in its narrowness as well as grudging and ineffectual...by disallowing their natures and stripping them of Godhead, as our current experts like to do, as though the Godhead feared some rival opposition from them or could produce nothing higher than creatures" (2003).

20 See Vaggione for more on the various theological levels of discourse (2008, 77ff).

${ }^{21}$ Gregory of Nyssa attacks Eunomius on this point from several angles; see Barnes (1998, 7379) for some of them. My aim here is to articulate an argument drawn only from the Nazianzen's work and which follows the trajectory began in Oration 23, Claim 2. 
retribution of both faith and works, and he will reign as king forever. (Apology 25)

According to this passage all relations between God and the world-creative, soteriological, and eschatological-obtain via the Son's activities. The problem with such a scheme is that the ontological separation between Father and Son precludes the sort of relationship necessary for these activities. Put another way, the Son cannot create, sustain, save, or reign if he is essentially distinct from the Father. To see why, recall that God shares nothing of his essence with the Son; Eunomius explicitly denies "any apparent similarity of essence" and reminds his reader that knowledge of God as Unbegotten "commands [the reader] to reject any comparison with another as being wholly foreign to the law of its nature."22 He emphasizes the point with an extended discussion of how God's nature

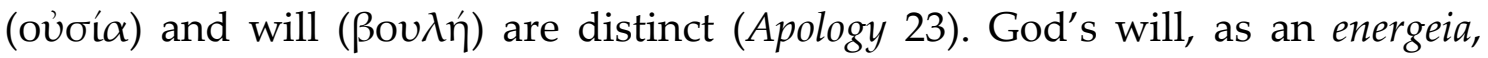
communicates nothing essentially to the Son. Stępień and Kochańczyk-Bonińska comment upon the "buffer" between Father and Son in Eunomius' system,

we can see that the generative act of will, which is not identical with essence, seems to be a kind of an entity between the Father and the Son. Therefore, the similarity of the Son to the Father is not a simple similarity of one substance to another, but rather the similarity of the substance of the Son, to the activity of the will of the Father. Making such a claim, Eunomius tries to preserve his opinion on dissimilarity of substances, and based on this principle, he goes further with an explanation how to understand the Son as the "image" ( $\varepsilon i \kappa \omega v)$ of the Father. He uses here [in Apology 24] the same scheme by saying that the Son is not the image of the Father, but rather the image of the activity of the Father. $(2018,162)$

The problem with Eunomius' position is that God's will, in relation to the Son, is purely causal activity. God does not share anything of his own with his Son-nor could he: given Eunomius' strong view of simplicity, any communication of intentions or emotions would be a communication of the divine essence. ${ }^{23}$ We can put the issue using Eunomius' causal terminology. For him there is no identity between essence and activity, thus God's essence is distinct from his will, as we have seen. Positively, this means that God's essence is 'will-less', non-wilful. The upshot is that when Eunomius describes the Son as the image of the Father's

22 Apology 20. Also Apology 22: "If, then, God is the only true and the only wise God because only he is unbegotten, the Son, being only-begotten because he is the Unbegotten's only offspring, could not in fact be anything 'only' at all if his nature were made to share a common

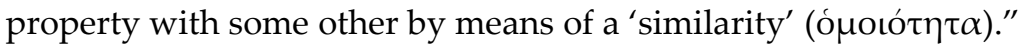

${ }^{23}$ God's name is 'Ingenerate' not merely because this best characterizes God, but because this is God's only characteristic. Cf. Apology 8. For more on Eunomius' identification of God's ingeneracy with his essence, and his essence with his existence, see Barnes (2016, 200-206). 
power and will, this means that the Son images an activity, not an essence. ${ }^{24}$ The Son, then, tells us nothing of the Father (an epistemological divide), ${ }^{25}$ and this because he has nothing of the Father's (an ontological one).

It seems that, to Eunomius' mind, the fact that God causes only one product is sufficient to make that product God's Son, and therefore God a father. However, we know that a father can produce a chair and produce a child. Even if he only produces the former, the chair is not his son. Though Gregory does not use this analogy, I think his reasoning follows this line. In Oration 20 Gregory attacks the ontological divide: "We must [not] be so partial to the Father that we actually strip him of his fatherhood, for whose father would he in fact be if his son were different in nature and estranged from him along with the rest of creation?" According to Gregory, the gap between the Father and Son is so great that the former cannot rightly be called Father.

This is problematic for Eunomius because, according to him, it is precisely the Father-Son relationship which ensures the success of the God-Demiurge-cosmos relationship. Stated in Eunomius' terms: an "Offspring" exists only if a parent does too; there can be an "obedient Son" only if he is actually a son; and one is the "most perfect Minister of the whole creation and will of the Father" only if God is a Father. Finally, the Only-begotten can minister "for the maintenance and preservation of all existing things" only if he is "rightly called" - that is, only if he actually is - a Son. To Gregory's mind, God and his product are so distantly related that they are little more than strangers. God is not a father; the Onlybegotten not a son; and the both are too disjoined for the latter to know and enact the former's will.

Summarizing dilemma 2 thus far: Eunomius carefully articulates the ontological gap between God and the Only-begotten. He seeks to bridge that gap by showcasing the similarity between the Son and the divine will. However, this bridge is too tenuous to support the theological freight which Eunomius seeks to send across. For Eunomius, the Father-Son relation is necessary for the Son to enact the Father's will (creatively, soteriologically, etc.). If that relation does not

\footnotetext{
${ }^{24}$ Eunomius interprets Paul's discussion of the Son as image as pointing "not to the unbegotten essence...but to the action through which the Son...came to be." He concludes, "The word 'image', then, would refer the similarity back, not to the essence of God, but to the action..." (Apology 24).

${ }^{25}$ Basil develops an epistemological argument along exactly this line. Citing Apology 20 where Eunomius argues for the strict distinction between substance and activity, Basil asks "how is it possible to reason back from created works to substance? ... For things which have been made are indicative of power and wisdom and skill, but not of the substance itself. Furthermore, they do not even necessarily communicate the entire power of the creator, seeing that the artisan can at times not put his entire strength into his activities." Basil iterates his conclusion, "For if the power has nothing in common with the substance, how could he be led from the created works, which are the effects of power, to the comprehension of the substance?" (Basil 2011, 2:32).
} 
obtain, as Gregory argues, then neither does God's will for creation, salvation, etc. Stated another way, two beings estranged by a complete lack of likeness could not share a common will, a common vision for the creation and providence of all other existents.

However, for the sake of argument let us assume that the Only-begotten does somehow have knowledge of and is in agreement with God's will. A state of affairs now obtains in which "God does not create, He commands creation (He commands into being a creature to carry out the command to create); God does not maintain and preserve all things but commands that all things be maintained and preserved, and so on" (Barnes 2016, 213). The problem here is that the Son is little more than a slave and God little better than a tyrant. In Oration 23 Gregory states the issue in more acerbic terms, averring that the heterousian "relegate[es] God to a position far removed from any real power, just as on earth of a tyrannical or avaricious bent do to those weaker than they" (10). ${ }^{26}$ God sits as far apart from creation as metaphysically possible and, from this distance, commands literally all his bidding be done. Gregory earlier argued that God's servant can hardly be called a 'son', and now presses the point to argue that the servant is little more than slave.

Additionally, God's will as cause of the Son give God no direct relation with creation. Gregory comments that "what shares the yoke of servitude cannot be defined as master, even if it represents the very best that the world of servitude and creation has to offer and is the only thing in this vile station to display the quality of loving-kindness." The Father does not relate to creation in love, but instead the Son 'does the loving for the both of them', further casting God as an aloof monarch. Even more unfortunate, the creature who delegates his power (and will) is just that: a creature. Though powerful by comparison to the rest of creation, the Only-begotten is subject to the same weaknesses of other created beings. If one thing is obvious, it is that created persons have a fundamental division between their will and God's; thus the Son would be prone to such volitional defect. ${ }^{27}$

Claim 3 is the idea that hierarchy among divine beings results in conflict. Claim 3 strengthens the idea, from Claim 2, that the Father does not share or communicate anything of his own in willing the Son. If true, this looks even more worrisome for the Eunomian than the previous claim, since here the Father and Son are not merely strangers, but outright enemies. One way Gregory may support this claim is to point out the Only-begotten does all the work in creation yet receives only a second share of the honour. After all, the Son is a creaturethough at the top of this "vile station" - and so his having enmity or jealousy is

26 Gregory here capitalizes on Eunomius' employment of language from the moral and political sphere to describe divine causation (see Barnes 1993, chp.10; 1998, 61-63, 68-70).

${ }^{27}$ Gregory of Nyssa gives a sustained attack on this front (see Barnes 1998, 73-79). 
quite plausible. This line of thought may have had traction with listeners who were accustomed to similar critique of the Greek pantheon, ${ }^{28}$ and later in Oration 23 Gregory moves in this direction saying that positing "disparate" and "diffuse" divine natures "is thoroughly...Greek and polytheistic" (40).

In sum, The Argument gives a brief attack on the ontological distance Eunomius places between God and the Only-begotten. With resources Gregory provides in Oration 23 and elsewhere, this attack can be shown to advance in several directions: it can include psychological estrangement (of desires and intentions); filial absence (so that the Only-begotten is not in fact God's son in any meaningful way); lowly servitude (where the Son serves the Father but has no relational connection or support); and the possibility - if not inclination - for the Only-begotten (as a mere created thing) to disagree with God's will. Gregory may point to any of these as good reasons for why there is conflict between divinities on the Eunomian view.

\section{The second horn of dilemma 1: a single divine nature}

In the face of these difficulties the Eunomian may choose to recognize the existence of one, and only one, divine nature. ${ }^{29}$ This route, too, presents worries. The problem is that a lone God is "constricted, mean, and not in a position to be the source of anything significant." What does Gregory have in mind here? A

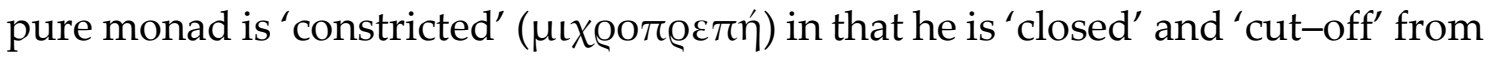
all others, ${ }^{30}$ reflected in the total lack of communication which makes him 'mean' ( $\sigma \tau \varepsilon v \eta \dot{v})$, or 'petty' - even 'underdeveloped' - in relation to all other existents.

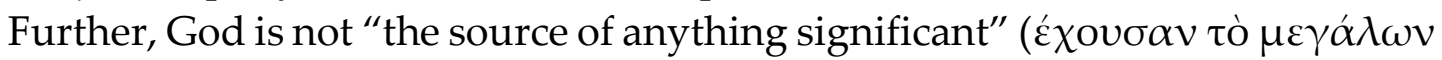

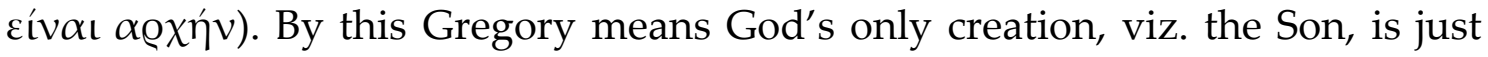
that: a mere creature. One who is powerful and active in the universe to be sure, but only as the topmost rung on a very finite ladder - a cosmic instance of gallum in suo sterquilinio plurimum posse. ${ }^{31}$ The Son's insignificance is made more acute when we take into consideration Gregory's formula that only that which is

28 Criticism of the gods for being at odds with one another came at least far back as Xenophanese (Fragments B11 and B12), later followed by Plato (Euthyphro, Republic). Gregory registers a complaint to this effect in Oration 27.6. Athanasius argues that a plurality of gods would necessarily lead to conflict of wills, rejecting the idea as impious and ridiculous (Against the Pagans 39). Eusebius argues along similar lines (Demonstrations of the Gospel 4:5).

29 Such a recognition probably excludes predicating deity to the Son even in an equivocal, analogical sense. If so, the Son is not to be viewed functionally divine as, for example, seen in claim that "he is therefore the Only-begotten God of those things which came into existence after him and through him" (Apology 15).

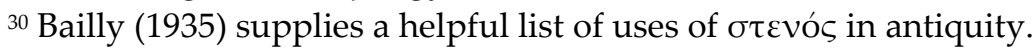

31 "Every cock crows upon his own dunghill." See Seneca Apocolocyntosis VII. 
assumed by God can be saved. ${ }^{32}$ All parties in the debate agree on the creative and soteriological accomplishments of the Son. Gregory argues that no mere creature, however highly placed among other creatures, can accomplish that work - rendering the Son insignificant along with the rest of creation. We have already seen Gregory fault Eunomius' position for making the Son wear "the yoke of servitude". Now Gregory presses the attack in arguing that the Son is the most pitiful of all creatures, since he is made only to bring about and save creation. In other words, the Son alone among all other creatures is purely a means to an end, rendering him even more "inconsequential and unworthy of divinity" since "everything that exists for the sake of something else is held in less esteem than the thing for which it was produced" (23.7). In sum, if there is only a single divine nature, then God's best and only product is quite pitiable, which reflects poorly upon God himself.

\section{Dilemma 3: God does not produce essentially because he cannot or will not}

Gregory advances the attack by considering why God would not share his essence in connatural production. To his mind there are only two possible explanations: God cannot, or God will not. Both explanations make the second lemma of dilemma 2 even more unattractive. This sort of argument is not unique to Gregory but had been used in various forms for some time. ${ }^{33}$ Origen argued thus,

And who that is capable of entertaining reverential thoughts or feelings regarding God, can suppose or believe that God the Father ever existed, even for a moment of time, without having generated this Wisdom? For in that case he must say either that God was unable to generate Wisdom before He produced her, so that He afterwards called into being her who formerly did not exist, or that He possessed the power indeed, but - what cannot be said of God without

32 "If anyone has put his trust in Him as a Man without a human mind, he is really bereft of mind, and quite unworthy of salvation. For that which He has not assumed He has not healed; but that which is united to His Godhead is also saved" (Gregory, 1894a).

33 Plato reasoned that the framer of the universe "was good, and what is good has no particle of envy in it" and so the best and highest god is both willing and able to share his goodness, resulting in another "blessed god" (Plato 1976, 4 \& 5). See also Phaedrus 247a: "...there is no envy ( $\varphi$ Өóvos) in the choir of the gods." Plotinus expanded upon the idea this way: How then could the most perfect remain self-set-the First Good, the Power towards all, how could it grudge or be powerless to give of itself, and how at that would it still be the source? If things other than itself are to exist, things dependent upon it for their reality, it must produce since there is no other source. And, further, this engendering principle must be the very highest in worth; and its immediate offspring, its secondary, must be the best of all that follows." (Plotinus 1991, 388) Note that both Plato and Plotinus' arguments point to a second divine being, but one that is subordinated in power and goodness to its progenitor. 
impiety - was unwilling to use it; both of which suppositions, it is patent to all, are alike absurd and impious. (Origen 1885. I.2.2)

This expression of the argument includes two ideas pertinent to Gregory's own. First, Origen argues that the Son is eternally generated, but the argument underdetermines the precise status of the Son's divinity. Gregory adapts this claim to fit his particular anti-Eunomian needs, strengthening it to conclude that the Son is produced essentially (and therefore eternally). ${ }^{34}$ Second, Origen argues if God does not share his essence, then God is impotent or unwilling. According to Origen, both options commit gross impiety. Gregory clarifies and expands upon this dilemma by showing just how bad the second option is. That is, God's will to not produce essentially can only be explained in two ways: God is either envious or fearful.

\section{Dilemma 4-God wills to not produce essentially out of envy or fear}

The final dilemma presents the Eunomian with two obviously unacceptable options. First, God wills to not share the divine essence with another due to envy "because [he] wishes to avoid the introduction of something that is of equal importance." Like Gregory, Eunomius recognizes that anything God produces connaturally is of equal value (Apology 9). Eunomius also recognizes that the honour due God is given in accordance to his place at the top of the hierarchy of being, as we have already seen. Thus, to avoid sharing his honour God refrains from producing connaturally. Second, God refrains from producing connaturally out of fear, "lest [the product] take on a hostile and belligerent element." In other words, God anticipates disagreement with a connatural hypostasis and, to avoid conflict with an equal, avoids having an equal altogether.

Coming from Gregory, this second lemma is curious because it looks to be as much a problem for his trinitarianism as it is for Eunomius'. On Gregory's view the Son is of equal value (power, wisdom, etc.) with the Father, and yet there is no conflict; indeed because of their shared goodness and will, there is no possibility for conflict. Eunomius could grant that, per impossibile, the Father shares his essence with the Son, then there would be no envy. Like Gregory, Eunomius would reject the lemma out of hand. It appears as if Gregory presents it more for the sake of structure (balancing The Argument with one dilemma after another)

${ }^{34}$ Basil $(2011,2.12)$ makes a similar move, "If being Father is good and fitting to the blessedness of God, how is that which is fitting for him not present in him from the beginning? For the lack will certainly be considered either a matter of ignorance of what is better or a matter of inability. As a matter of ignorance, if he discovered what is better only later; as a matter of inability, if while knowing and understanding it he failed to attain what is best." 
or rhetorical points (mis-characterizing one's opponents was a move neither party was above making when they thought they could get away with it).

\section{The Argument and Gregory's trinitarian theology}

In The Argument, Gregory identifies and seeks to exploit several points of tension within the Eunomian doctrine of the Son's deity. While Gregory is correct to press on these tensions, The Argument is not a knock-down one. The committed Eunomian would happily grant the first horn of Dilemma 3, viz., that God does not share the divine nature because he cannot. All parties agree that there are certain actions impossible for God, and sharing the divine essence tops the Eunomian's list. Thus God is impotent in regards to connatural production, but only trivially since such production is impossible. God is no worse off for not essentially begetting a son than he is for not creating square circles. Similarly, God may be mean, but this too is trivial since God does not give what is impossible to give. Finally, a monadic God may be constricted but, from the Eunomian perspective, this highlights God's complete otherness: one theologian's divine constriction is another's divine transcendence.

The Eunomian's best option, then, is to stick to her original claim that God does not share the divine essence because he cannot, and to then point out that any attributions of meanness, constriction, or impotence are either vacuous or actually signal her high view of divine transcendence. With his opponent having dug-in her heels, how may Gregory move forward? Short of attacking her metaphysics of causation head-on-which he does not attempt-I'm not sure Gregory could dislodge the entrenched Eunomian.

In Oration 23 Gregory instead proceeds in two ways. Negatively, he continues the rhetorical attack on the Eunomian position; positively, he contrasts the unseemly commitments in Eunomianism with attractive elements from his own trinitarian theology. I will conclude this essay by focusing on Gregory's deployment of this two-fold strategy along the lines of honour, one of the primary themes of the oration and a theme important to Eunomius. ${ }^{35}$ Generally, Gregory thinks of honour axiologically: the greater a thing, the more honourable it is. Practically, this leads us to commend, praise-and for the most honourable object-worship.

35 The concept of honour is used throughout the Apology. Early in the tract Eunomius implores his followers to "honour the teaching of our Saviour Jesus Christ" by believing the truth of his (Eunomius) message (2). Once Eunomius begins his argument proper he quickly employs honour as part of the reason for positing a single God, since there must exist a single source having "the dignity of the Godhead" (7). He next explains that to be unbegotten is to be most worthy of honour (Apology 8). He finishes the tract with the warning that "those who through ill-will have dishonoured" the true faith face inexorable punishment (27). 
Following the two-fold strategy, Gregory first critiques Eunomius' doctrine for dishonouring God, the Son, and the Spirit. Gregory then argues that his view of connatural production holds the higher view of God's honour. The following argument sketches the main lines of attack,

In fact, God is the object of proportionately more honour than his creatures are to the degree that it is more in keeping with the greater majesty of the first cause to be the source of divinity rather than of creatures and to reach the creatures through the medium of divinity rather than the reverse, that is, for divinity to acquire substantive existence for their sakes, as our very subtle and high-flown thinkers imagine. $(23.6)^{36}$

Akin to perfect being theology, we may describe this form of argumentation as perfect honour speculation. The passage above contains two arguments. The first, stated very roughly: it is more honourable to produce essentially than not. ${ }^{37}$ The second parallels the first: it is more honourable for God to save creatures through another divine being than through a creature. The success of both arguments depends on the principle that, ceteris paribus, a doctrine which posits a higher view of God is to be preferred-call this the Greatest Honour principle. This principle is used again in the following two-part argument (I will number both parts),

Or are you unaware that in regarding God as the source of "creatures," by which I mean the Son and the Holy Spirit, you [1] not only fail to honour the source but you [2] also dishonour whatever issues from it?" (23.7)

${ }^{36}$ Oration 23.6. A similar argument is made in 23.7: "For if, while admitting the dignity of the Son and the Holy Spirit, we implied that they are either without source or from a different source, we should in fact face the terrible risk of dishonouring God or of setting up a rival deity. But if, no matter how highly you exalt the Son or the Spirit, you... attribute their noble generation and marvellous procession to him, I shall simply ask you... who dishonours God more, the one who regards him as the source of the kinds of beings you yourself introduce, or the one who regards him as the source not of such, but of those which are like him in nature and equal to him in honour, the kind that our doctrine professes?"

${ }^{37}$ We may outline the first argument in a bit more detail this way:

1. A cause is greater than its effect. (A Platonic principle accepted by all in the debate).

2. Therefore, the greater the effect, the greater cause.

3. A divine being is greater than a created one. (Another shared assumption).

4. Therefore, if God causes a divine being, he is greater than if he (only) causes creatures.

5. God is honourable to the degree he is great. (A shared assumption).

6. Therefore, if God causes a divine being, he is more honourable than if he (only) causes creatures. 
Gregory explains part 1 saying, "You dishonour the source by referring it to beings that are inconsequential and unworthy of divinity". This explanation is a straightforward employment of the Greatest Honour principle and parallels the argument we just looked at. In the next part Gregory expands the range of his critique,

you dishonour the issue, by making them inconsequential, and not merely creatures, but of all creatures the least honoured. If in fact it was for the sake of these creatures that the Son and the Spirit came into existence at some point in time, like a craftsman's tools that do not exist before the craftsman has made them, their only reason for being would be that God chose to use them to create something, on the grounds that his will was not enough; for everything that exists for the sake of something else is held in less esteem than the thing for which it was produced. (23.7)

Part 2 specifies the Son's truly low worth, since he is valuable only insofar as he is a means to an end. If Gregory is correct about means being less valuable than their ends, then, contrary to intuitions, creation is ranked higher than the Onlybegotten. Having argued for the immensely low degree of honour afforded to the Son by non-homoousian views, Gregory immediately employs the Greatest Honour principle positively.

I, on the other hand, by positing a source of divinity that is independent of time, inseparable, and infinite, honour both the source as well as its issue: the source, because of the nature of the things of which it is the source; the issue, because of their own nature as well as of the nature of the source from which they are derived, because they are disparate neither in time, nor in nature nor in holiness. (23.8)

Here Gregory directly contrasts his view with the Eunomian's. For Gregory, the Father's essential production of the Son and Spirit ensure that all parties are rightly elevated in dignity. The extent of their honour is showcased most powerfully when Gregory describes God's monarchy, that is, the nature of the Father's essence which he gives to Son and Spirit,

a nature that is in internal agreement with itself, is ever the same, ever perfect, without quality or quantity, independent of time, uncreated, incomprehensible, never self-deficient, nor ever so to be, lives and life, lights and light, goods and good, glories and glory, true and truth, and Spirit of truth, holies and holiness itself; each one God, if contemplated separately, because the mind can divide the indivisible; the three God, if contemplated collectively, because their activity and nature are the same; which neither rejected anything in the past as superfluous 
to itself nor asserted superiority over any other thing for there has been none; nor shall leave anything to survive it or will assert superiority over anything in the future, for there will be none such; nor admits to its presence anything of equal honour since no created or servile thing, nothing which participates or is circumscribed can attain to its nature, which is both uncreated and sovereign, participated in and infinite. (23.9)

Read in its polemical context and with an eye toward the theme of honour, we are in a position to feel some of the force of this passage. For here we encounter a list of the glories the Father shares with his Son and Spirit, including perfection, complete fullness, and activity. The prose is a majestic presentation of the riches of the Godhead, part of Gregory's overarching intention to make his theologizing truly 'theological.' Beeley outlines some of what this entails,

In Gregory's view, Christian theology involves and represents a dynamic, live relationship between God and the theologian, and so it begins not with abstract information about God...but with the transformation of the theologian within the horizon of God's presence and activity in the world, as it is recognized and celebrated in the life of the church. (Beeley, 2008, 64)

Gregory enacts this transformation by presenting the great dignity due to Father, Son and Spirit in hopes that it leads to actual honour and worship from his congregants. At the same time, interwoven among beautiful prose is some technical and precise conceptual work. For example, Gregory employs the ' $X$ from $X^{\prime}$ language common since the third century (see Ayres 2004, chps. 6 \& 7). Whereas in many writers such language is ambiguous, here it is quite precise, introducing a participation metaphysics to clarify the exact nature of "light from light," etc.

Beyond the polemic sphere we may compare the Apology with The Argument and Oration 23. On the one hand we have Gregory's masterful weaving of technical precision with affective force and the ultimate goal of a living theology. Contrasted with Eunomius' focus on technical precision alone, we see how Gregory's teaching successfully crafted a "narrative theology", one which

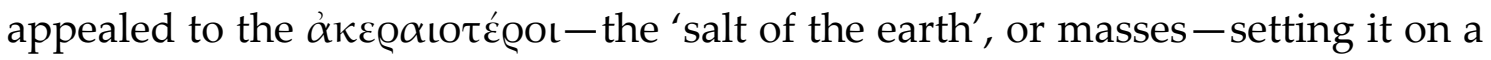
trajectory for becoming the dominant view (Vaggione 2008, 77ff).

\section{Conclusion}

In Oration 23 Gregory modifies a traditional piece of triadic speculation to fit his particular needs. Polemically, those needs include showing the pitfalls of heterousian, homoian, and pneumatomachian doctrines of the Son's deity. Rhetorically, The Argument slots comfortably into Gregory's employment of 
honour as an argumentative device, showing his full-blown homoousianism to be at once more honouring to the Father as well as the Son and Spirit. Finally, Gregory makes the argument approachable for 'the masses' by focusing on affectively powerful, rhetorical points. Even so, it affords him the chance to offer a nuanced positive trinitarian theology that would satisfy those with more theological training. ${ }^{38}$

\section{Bibliography}

St. Athanasius. 1892. De Decretis. http://www.newadvent.org/fathers/2809.htm.

St. Athanasius. 1892. Tome of Antioch. https://www.elpenor.org/athanasius/letterantioch.asp?pg=5.

Ayers, Lewis. 2004. Nicaea and Its Legacy. Oxford: Oxford University Press. https://doi.org/10.1093/0198755066.001.0001.

Bailly, Anatole. 1935. Le Grand Dictionnaire grec-français. Paris: Hachette.

Barnes, Michele René. 1998. "Eunomius of Cyzicus and Gregory of Nyssa: Two Traditions of Transcendent Causality." Vigiliae Christianae 52, n.1. February: 59-87. https://doi.org/10.2307/1584584.

Barnes, Michele René. 2016. The Power of God: Dynamis in Gregory of Nyssa's Trinitarian Theology. Washington D.C. The Catholic University of America Press.

Barnes, Michele René. 1993. “The Background and Use of Eunomius' Causal Language." Arianism After Arius. Edited by M.R. Barnes and D.H. Williams. T.\&T. Clark.

Basil of Caeserea. 1895. De Spiritu Sancto. http://www.newadvent.org/fathers/3203.htm.

Basil of Caeserea. 2011. Against Eunomius. Translated by Mark Delcogliano and Andrew Radde-Gallwitze. Washington D.C. The Catholic University of America Press.

Beeley, Christopher. 2008. Gregory of Nazianzus on the Trinity and the Knowledge of God. Oxford:

O.U.P. https://doi.org/10.1093/acprof:oso/9780195313970.001.0001.

Browne, C.G. and J.E. Swallow. 1886. A Select Library of Nicene and Post-Nicene Fathers. Mass.: Hendrickson.

Davis, Stephen. 2016. Christian Philosophical Theology. Oxford: Oxford University Press.

Eunomius. 1987. Eunomius: The Extant Works. Prepared and translated by R.P. Vaggione. Oxford: Clarendon Press.

\footnotetext{
${ }^{38}$ My gratitude to Oliver Crisp, Oliver Langworthy, and Matthew Joss for comments on an earlier draft of this essay. Special thanks to Beau Branson for first bringing this text to my attention.
} 
Gregory of Nazianzus. 2003. St. Gregory of Nazianzus: Select Orations. Translated by Martha Vinson. Washington D.C: The Catholic University Press.

Gregory of Nazianzus. 1894. Epistle 101: To Cledonius the Priest Against Apollinarius. http://www.newadvent.org/fathers/3103a.htm.

Gregory of Nazianzus. 1894. Oration 31.14, The Fifth Theological Oration. http://www.newadvent.org/fathers/310231.htm.

Gregory of Nazianzus. 1857-1866. Patrologiae Graecae. Edited by J.P. Migne. Paris: Imprimerie Catholique.

Hasker, William. 2013. Metaphysics and the Tri-personal God. Oxford: Oxford University Press. https://doi.org/10.1093/acprof:oso/9780199681518.001.0001.

Langworthy, Oliver B. 2019. Gregory of Nazianzus' Soteriological Pneumatology. Mohr Siebeck.

McGuckin, J.A.. 1994. "Perceiving Light from Light in Light." The Greek Orthodox Theological Review 39 n.1 (January): 7-32.

Origen. 1885. On First Principles. http://www.newadvent.org/fathers/04121.htm.

Plato. 1976. Timaeus and Critias. 4 and 5. Translated by Desmond Lee. Middlesex: Penguin Books.

Plotinus. 1991. The Enneads. Translated Stephen MacKenna. London: Penguin Books.

Stępień, Tomasz and Karolina Kochańczyk-Bonińska. 2018. Unknown God, Known in His Activities. Oxford: Peter Lang. https://doi.org/10.3726/b14190.

Swinburne, Richard 1994. The Christian God. Oxford: Oxford University Press. https://doi.org/10.1093/0198235127.001.0001.

Vaggione, R.P. 2008. Eunomius of Cyzicus and the Nicene Revolution. Oxford: Oxford University Press.

Published Online: February 18, 2020 